\title{
VARIATIONS IN BIRCH POLLEN (Betula spp.) SEASONS IN LUBLIN AND CORRELATIONS WITH METEOROLOGICAL FACTORS IN THE PERIOD 2001-2010. A PRELIMINARY STUDY
}

\author{
${ }^{1}$ Krystyna Piotrowska, ${ }^{2}$ Bogusław Michał Kaszewski \\ ${ }^{1}$ Department of Botany, University of Life Sciences, Akademicka 15, 20-095 Lublin, Poland \\ ${ }^{2}$ Department of Meteorology and Climatology,Maria Skłodowska-Curie University, al. Kraśnicka 2cd, 20-718 Lublin, Poland \\ e-mail: krystyna.piotrowska@up.lublin.pl
}

Received: 12.01.2011

\begin{abstract}
In Poland birch belongs to the most important taxa producing allergenic pollen, therefore information on the start dates, duration and severity of the pollen season is very important for allergists and their patients as well as for climatologists. Birch pollen monitoring was conducted in Lublin using the volumetric method during the period 2001-2010. A Lanzoni VPPS 2000 trap was placed at a height of $18 \mathrm{~m}$ in the city centre. The pollen season was determined using three methods: $98 \%$, $95 \%$, and $90 \%$. The present study also investigated correlations between the birch pollen season parameters and meteorological factors. A comparison of the above-mentioned methods shows that, in the conditions prevailing in Lublin, the most appropriate method to determine the birch pollen season is the $98 \%$ method, since in the case of the two other methods too large quantities of pollen grains are eliminated. Based on a comparative analysis of the meteorological data from the study period and the long-term averages, it can be concluded that in the recent years a clear increase in air temperature has been recorded in Lublin. The study found a statistically significant negative correlation of seasonal pollen concentration with rainfall and air humidity. When the pre-peak and post-peak periods were separated, these correlations were larger and related to different meteorological factors. The start of the pollen season was negatively correlated with temperature in February and March. The season duration depended on temperature (a positive correlation). The date of the seasonal maximum was positively correlated with seasonal temperature and negatively with temperature in April.
\end{abstract}

Key words: Betula pollen season, meteorological factors, Spearman's correlations

\section{INTRODUCTION}

Plants definitely improve the quality of life in a city. They remove from the atmosphere gas pollu- tion from human activity, modify temperature, reduce insolation and noise, increase air humidity, reduce the wind, and neutralize radioactive radiation $(\mathrm{C} h$ i e s u $\mathrm{ra}$, 2004). It has been proven that hospital patients with a view of greenery recover more quickly (Ulrich, 1984).

A particularly positive influence on human health is attributed to birch. The vicinity of birch trees has a beneficial effect on human organism, since trees emanate healing energy. Birch leaves as well as twigs and bark are used in herbal medicine; the sap collected in the spring from tapped trees also has therapeutic activity (U r y g a , 2002). Male inflorescences of various Betula species are extensively visited by bees. Pollen loads formed by bees from the pollen of this taxon are yellow-coloured (Maurizio and Graf1, 1969). Varying birch pollen contents are also found in honeys (W a r a k o m s k a , 1997). Birch pollen contains $21.9 \%$ of protein and $2.7 \%$ of lipids. It is considered to be the most valuable protein food for bees ( $\mathrm{B}$ a n a s zak, 1993). Maurizio (1953) found a very positive effect of birch pollen on the life span of bees and their physiological condition. Birch buds and leaves are also a source of resin collected by bees. In the summer bees collect honeydew from birch leaves (B a n a s zak, 1993).

Among several species of the genus Betula growing in natural stands in Poland, the most common is B. pendula ( $\mathrm{S} \mathrm{z}$ w e y k ow s c y, 1993; K r e m e r, 1996). It is found most frequently in forest communities, but can also be encountered on dry sands and in wetlands. $B$. pendula is characterized by high resistance to climatic conditions and atmospheric pollution. Due to this, it is often used in urban plantings. 
In the recent years, there has been observed an increased incidence of allergies, in particular pollen allergies. In Poland birch belongs to the main plants causing pollinosis during the spring period. The pollen of birch contains severe allergens that are quickly released in contact with the respiratory mucous membranes (N i l s s o n, 1990; V i k et al. 1991). It is a frequent cause of pollinosis in Europe. It has been shown that $20-25 \%$ of patients suffering from pollen allergies react to the pollen of this taxon ( $\mathrm{Vik}$ et al. 1991).

The aim of the present study was to analyse the patterns of birch pollen seasons in the conditions of Lublin over a period of ten years. This study compared three percentage methods that are used in aerobiology to determine the start and end dates of pollen seasons. The study results are presented in relation to meteorological factors.

\section{MATERIAL AND METHODS}

The study material consisted of airborne Betula pollen grains trapped in Lublin. The climate of the study area is temperate. It is characterized by high weather variability and significant variations in seasonal weather patterns in particular years (K a s z e w s ki, 2008). According to average temperatures based on 60-year temperature records (1951-2010), the coldest month of the year is January (mean temperature $-2.8^{\circ} \mathrm{C}$ ), while the warmest month is July (mean temperature $19.0^{\circ} \mathrm{C}$ ). In the month of April, in which the highest birch pollen concentrations are recorded in the air of Lublin, average temperature is close to mean annual temperature and it is $8.5^{\circ} \mathrm{C}$. Mean annual total precipitation is $551 \mathrm{~mm}$. Maximum rainfall is recorded in July $-79 \mathrm{~mm}$, while minimum precipitation in January $-28 \mathrm{~mm}$. In April total rainfall is $38 \mathrm{~mm}$.

Betula pollen monitoring was carried out continuously from 2001 to 2010. A Hirst - type trap, Lanzoni VPPS 2000, was used. The pollen sampler was placed on the flat roof of the building of the Lublin University of Life Sciences $18 \mathrm{~m}$ above ground level $\left(\lambda=22^{\circ} 32^{\prime} 25^{\prime \prime} \mathrm{E}\right.$ and $\varphi=51^{\circ} 14^{\prime} 37^{\prime \prime} \mathrm{N}$; $197 \mathrm{~m}$ a.s.1.). Single Betula pendula individuals are found near the sampling site. The genus Betula is represented in the region of Lublin by the following species: $B$. pendula, $B$. pubescens, and $B$. humilis $(\mathrm{Z} \mathrm{ając}$ and $\mathrm{Zaj} a ̨ \mathrm{c}$, 2001).

Pollen grains were identified and counted in four horizontal lines; subsequently, mean daily pollen counts were calculated. The following methods were used to determine the start and end dates of the pollen seasons: $98 \%, 95 \%$, and $90 \%$. According to the $98 \%$ method, the onset of the season was determined to occur when $1 \%$ of birch pollen was recorded in the total annual pollen count, whereas the end of the season when $99 \%$ of pollen grains was recorded. According to the $95 \%$ and $90 \%$ methods, the season began when, respectively, $2.5 \%$ and $5 \%$ of pollen grains were trapped, while the end occurred when $97.5 \%$ and $95 \%$ of the total annual pollen count were noted.

The following meteorological data were used for the analysis: mean, minimum, and maximum air temperature, relative air humidity, rainfall, cloud cover, and wind speed. The meteorological data came from the Meteorological Observatory of the Meteorology and Climatology Department, the Maria CurieSklodowska University in Lublin; this Observatory is located at a distance of about $1.5 \mathrm{~km}$ from the pollen sampling site. The Spearman's correlation coefficients were calculated to demonstrate correlations between the pollen season parameters and weather.

\section{RESULTS}

During the period 2001-2010, birch pollen grains were recorded in the air of Lublin from the beginning of April, with the exception of the cold years of 2003 and 2006, when the pollen of birch appeared, respectively, in the second and first decade of April. Figures $1-3$ show a comparison of the duration of the pollen seasons as well as their start and end dates, as determined by the above-mentioned different methods. The shortest duration of the birch pollen season was obtained when the $90 \%$ method was applied (on average 18 days). According to the $95 \%$ and $98 \%$ methods, the pollen season lasted on average 24 days or 32 days (Table 1). The pollen season determined by the $98 \%$ method started on average on 12 April and ended on 13 May. If the $95 \%$ and $90 \%$ methods were used, the average start dates of the pollen season were recorded 3 days later than in the case of the $98 \%$ method, while the end of the season was observed, on average, 6 days earlier (95\% method) or 11 days earlier (90\% method) (Table 1, Figs 1-3).

Very large differences were found in the start and end dates of the pollen seasons in the particular years. A comparison of the earliest and latest start date of the season shows that, depending on the method, in the period 2001-2010 this difference was 19 days (98\% method), 14 days (95\% method), or 13 days (90\% method). Over the ten-year study period, the variation between the season end dates was 18 days $(98 \%$ method), 19 days (95\% method), or 11 days (90\% method) (Figs 1-3). 


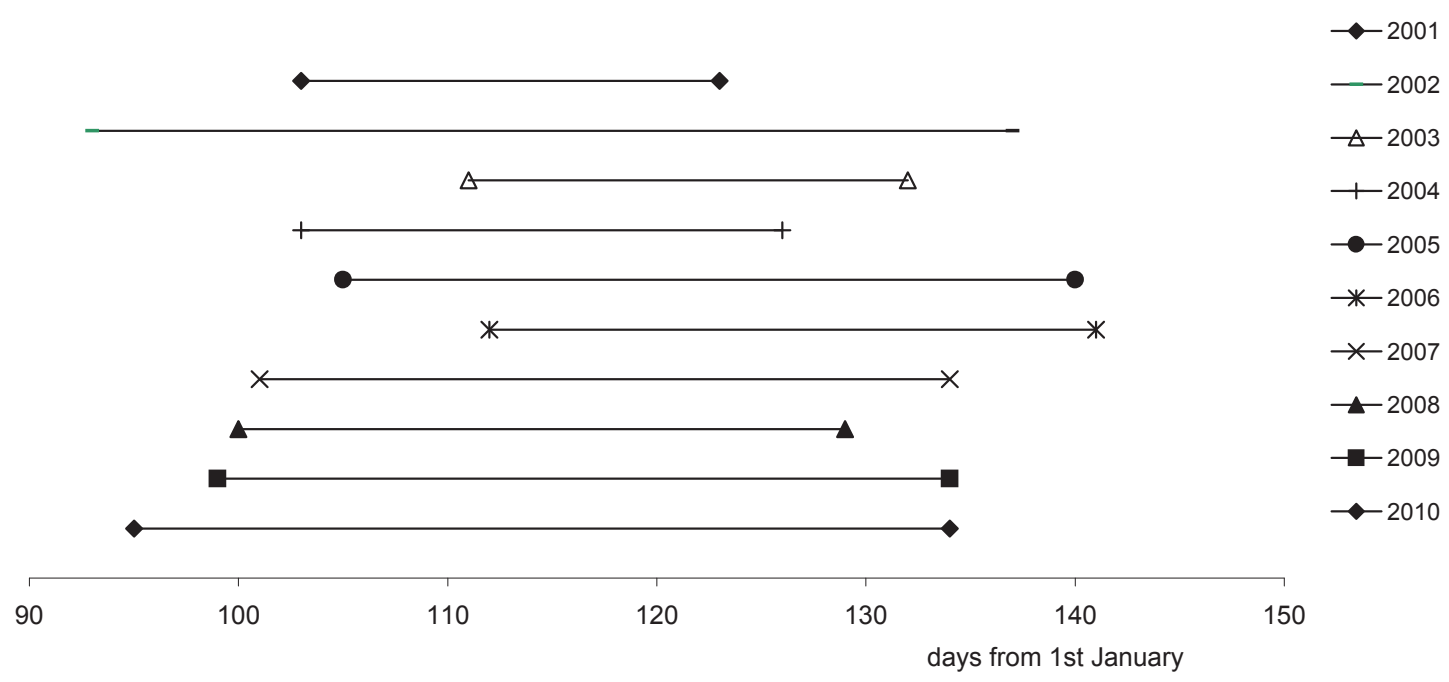

Fig. 1. The start and end dates of the birch pollen season in Lublin in the 2001-2010 years (98\% method).

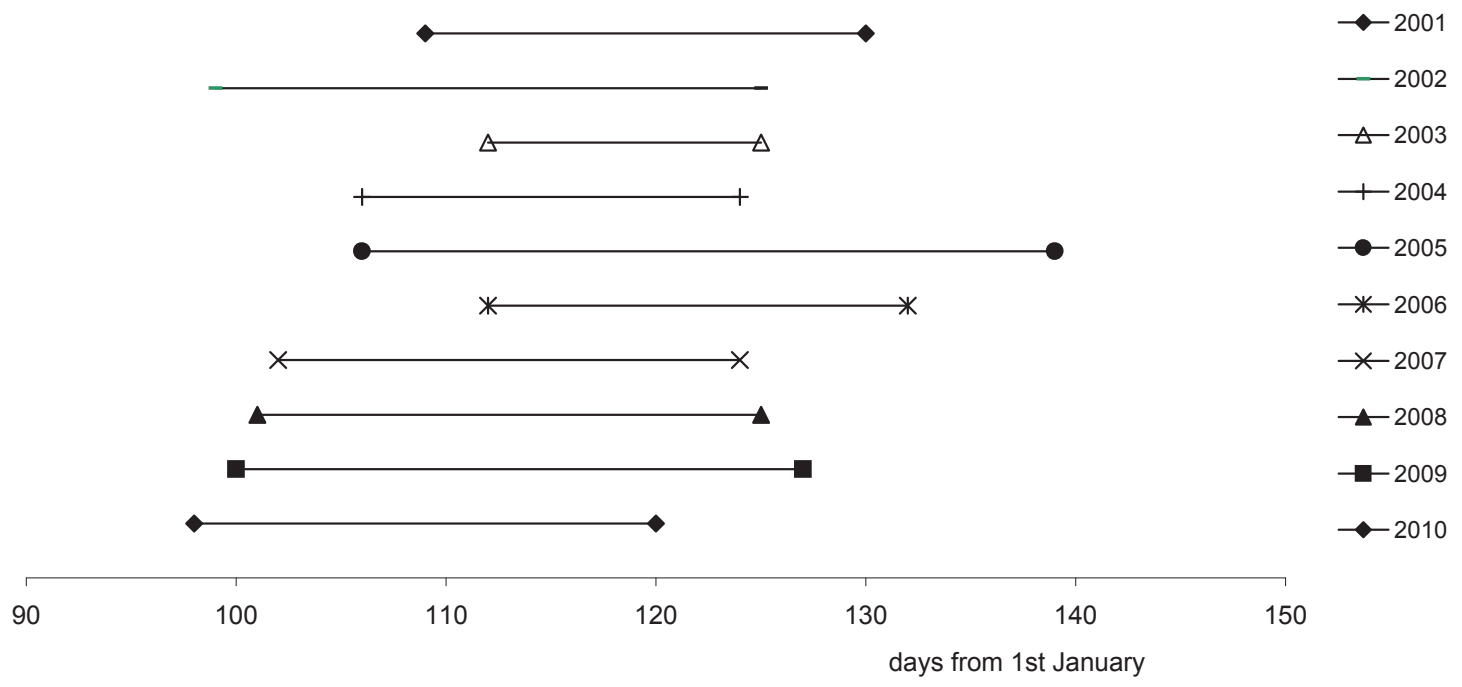

Fig. 2. The start and end dates of the birch pollen season in Lublin in the 2001-2010 years (95\% method).

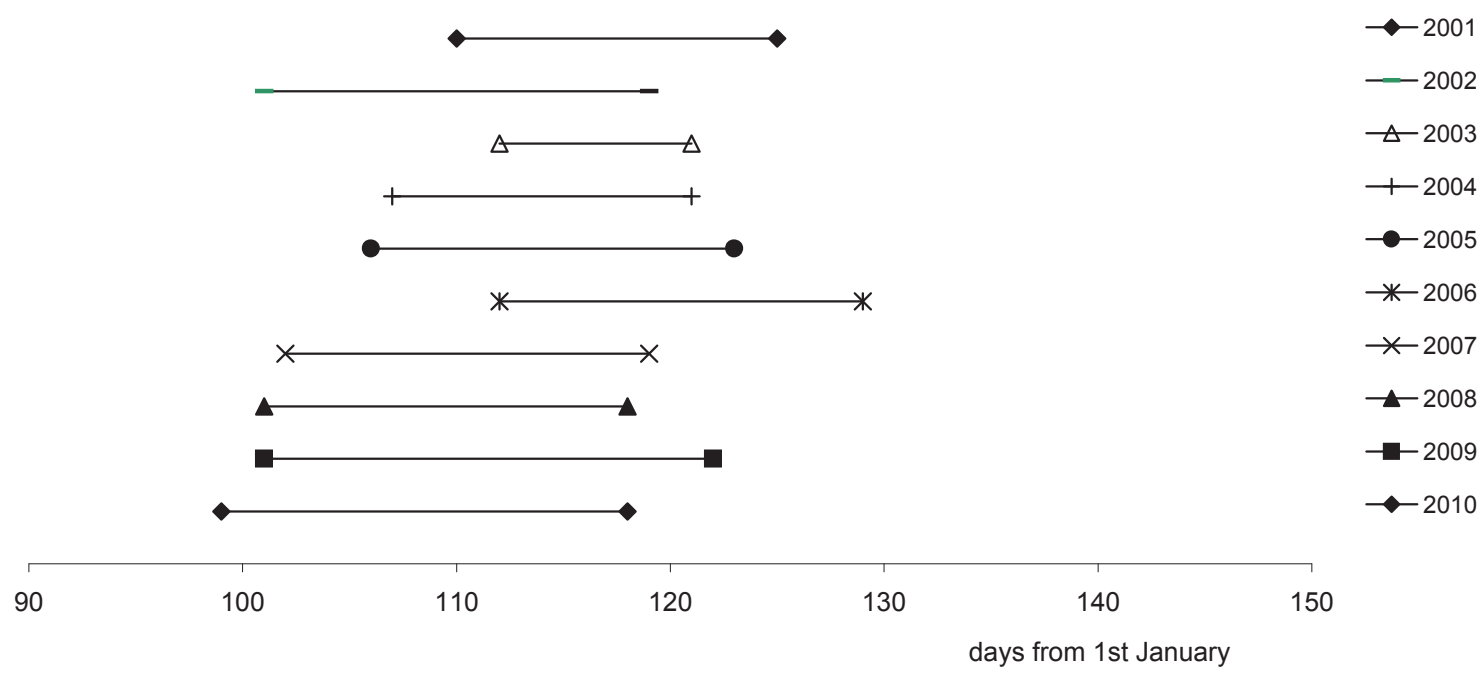

Fig. 3. The start and end dates of the birch pollen season in Lublin in the 2001-2010 years (90\% method). 
Table 1.

Characteristics of the birch pollen seasons determined by three methods

\begin{tabular}{ccccc}
\hline Method & Season parameter & Mean & Minimum & Maximum \\
\hline $98 \%$ & Start & 12.04 & 3.04 & 22.04 \\
$95 \%$ & & 15.04 & 8.04 & 22.04 \\
$90 \%$ & & 15.04 & 9.04 & 22.04 \\
\hline $98 \%$ & End & 13.05 & 3.05 & 21.05 \\
$95 \%$ & & 7.05 & 30.04 & 19.05 \\
$90 \%$ & & 2.05 & 28.04 & 9.05 \\
$98 \%$ & \multirow{2}{*}{ Duration } & 32 & 19 & 42 \\
$95 \%$ & & 24 & 14 & 34 \\
$90 \%$ & & 18 & 10 & 22 \\
\hline
\end{tabular}

The pollen season started the latest in the years 2003 and 2006 due to the prolonged period of low temperatures. The start dates of the season in these years determined according to the three methods coincided (Fig. 4). The largest difference (8 days) in the start date of the pollen season, as determined by the three methods, was in the year 2002 in which the pollen season started the earliest (Fig. 4). The season end dates in the particular years determined by these different methods distinctly varied (Fig. 5).

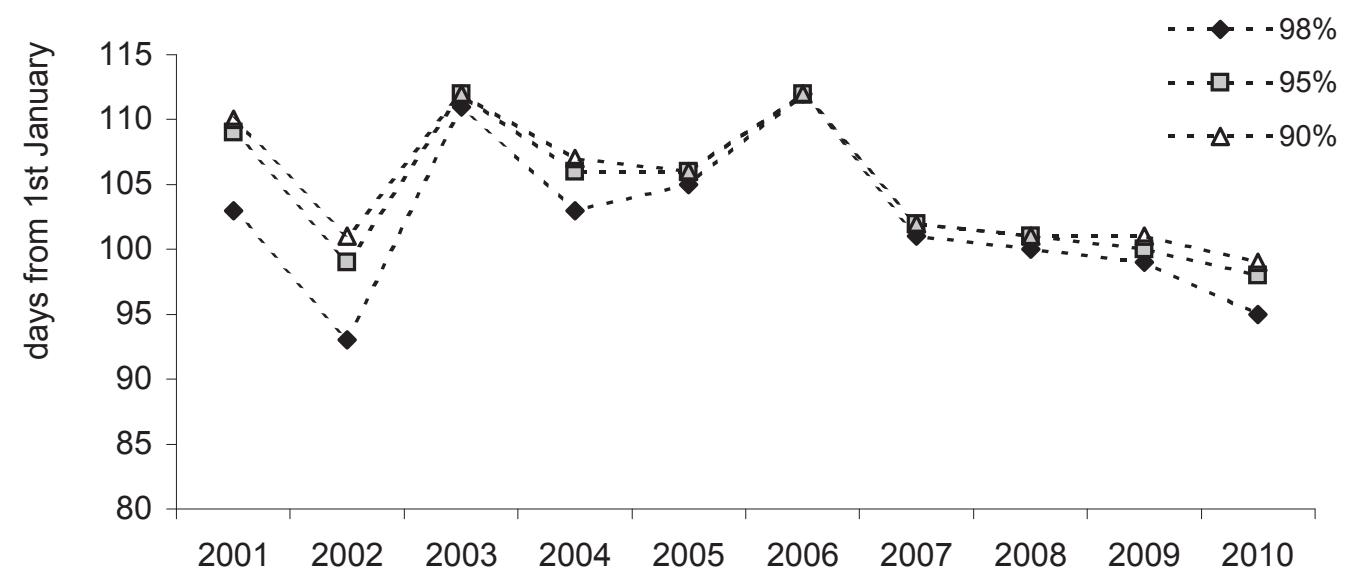

Fig. 4. A comparison of the start dates of the birch pollen season in Lublin in the period 2001-2010 calculated by three methods $(98 \%, 95 \%$, and $90 \%)$.

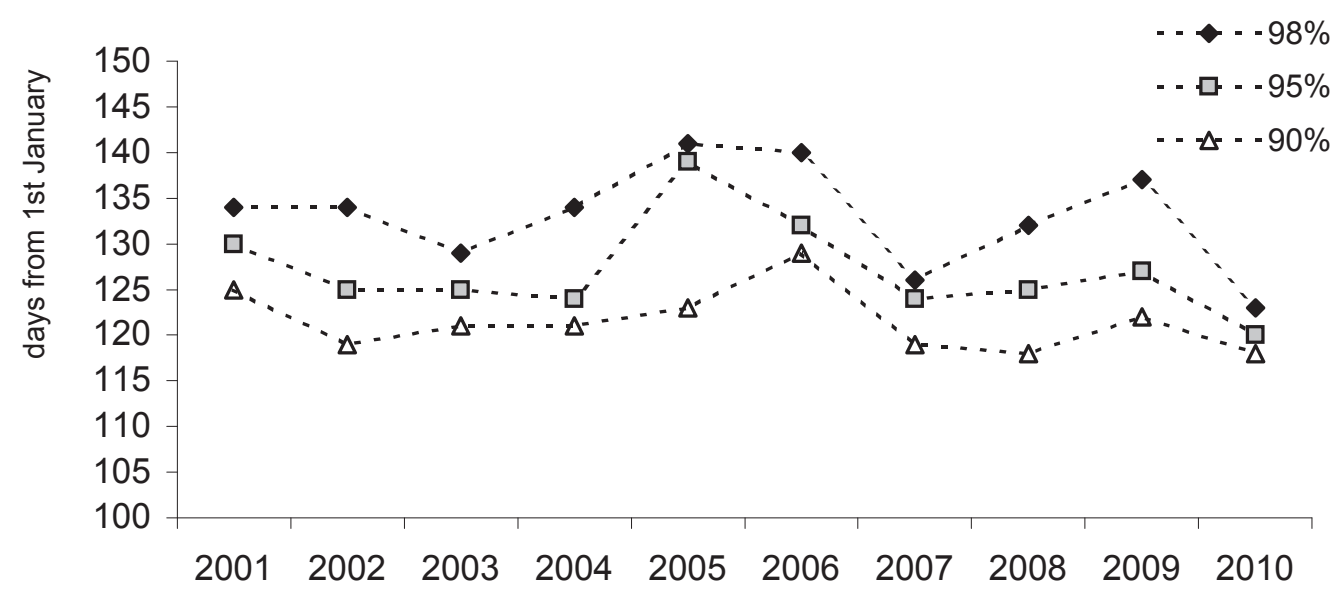

Fig. 5. A comparison of the end dates of the birch pollen season in Lublin in the period 2001-2010 calculated by three methods (98\%, 95\%, and 90\%). 
Table 2.

The annual total as well as the differences between the annual total and the seasonal pollen index (SPI) calculated using the $98 \%, 95 \%$, and $90 \%$ methods

\begin{tabular}{ccccc}
\hline Year & $\begin{array}{c}\text { Annual } \\
\text { total }\end{array}$ & \multicolumn{3}{c}{ Cut off pollen grains number in methods: } \\
& 13670 & 268 & $95 \%$ & $90 \%$ \\
\hline 2001 & 5354 & 93 & 586 & 741 \\
2002 & 34134 & 346 & 253 & 384 \\
2003 & 12647 & 166 & 1181 & 2002 \\
2004 & 6951 & 56 & 590 & 1605 \\
2005 & 22899 & 278 & 333 & 697 \\
2006 & 17412 & 284 & 517 & 1196 \\
2007 & 24183 & 282 & 458 & 1133 \\
2008 & 3266 & 47 & 821 & 1515 \\
2009 & 23076 & 311 & 113 & 289 \\
2010 & 16359 & 213 & 942 & 1960 \\
\hline average & & & 579 & 1152 \\
\hline
\end{tabular}

Quite significant amounts of airborne pollen are sometimes not taken into account in determining the timing of pollen seasons by the percentage methods. Depending on the method used, different numbers of pollen grains are excluded from the respective pollen season. Table 2 shows pollen sums that were omitted when determining the pollen seasons using the $98 \%$, $95 \%$, and $90 \%$ methods. In the year 2003, in which the highest concentrations were recorded, these values were in the range 346 (98\% method) - 2002 pollen grains (90\% method) (Table 2). When the 95\% method was applied, or in particular the $90 \%$ method, some days with a pollen concentration much exceeding the threshold value $\left(80 \mathrm{P} / \mathrm{m}^{3}\right)$, at which an allergic response to the pollen of birch occurs in all pollen allergy sufferers, are eliminated from the calculations relating to the season. For this reason, the pollen season calculated using the $98 \%$ method was used for further analysis.

In the period in question (2001-2010), mean annual air temperature was $9.1^{\circ} \mathrm{C}$ and it was higher by $1.0^{\circ} \mathrm{C}$ compared to the period 1951-2000. An increase in temperature was observed in all the months under study (Table 3). The highest increase, by $1.4^{\circ} \mathrm{C}$, was in April, i.e. in the month in which the highest birch pollen concentration was observed. At the same time, the difference in temperature between March and April increased (by $0.2^{\circ} \mathrm{C}$ ) to $6.6^{\circ} \mathrm{C}$.

Table 3

Temperature and precipitation conditions in January-April 2001-2010 relative to the period 1951-2000

\begin{tabular}{cccccccccc}
\hline & \multicolumn{4}{c}{ Temperature $\left({ }^{\circ} \mathrm{C}\right)$} & \multicolumn{3}{c}{ Precipitation $(\mathrm{mm})$} \\
\cline { 2 - 10 } Years & \multicolumn{4}{c}{ months } & \multicolumn{4}{c}{ months } \\
\cline { 2 - 10 } & I & II & III & IV & I & II & III & IV \\
\hline $2001-2010$ & $-2,2$ & $-0,9$ & 3,1 & 9,7 & 31 & 31 & 37 & 35 \\
\hline $1951-2000$ & $-3,0$ & $-2,0$ & 1,9 & 8,3 & 27 & 28 & 28 & 39 \\
\hline Variations & $+0,8$ & $+1,1$ & $+1,2$ & $+1,4$ & +4 & +3 & +9 & -4 \\
\hline
\end{tabular}

Mean annual total precipitation in the period 2001-2010 was $569 \mathrm{~mm}$ and it was higher by $22 \mathrm{~mm}$ compared to the period 1951-2000. Higher precipitation levels were recorded in January, February, and March, while rainfall in April was lower by $4 \mathrm{~mm}$.

The present study investigated the effect of weather on birch pollen concentrations. In order to show correlations between the seasonal features and meteorological factors, the Spearman's correlation coefficients were calculated. Rainfall and relative air humidity were found to have the greatest effect on seasonal birch pollen concentration (Table 4). The patterns of daily birch pollen concentrations relative to meteorological factors were also analysed in the 
pre-peak and post-peak period. In the pre-peak period, pollen concentration was positively correlated with mean, minimum, and maximum air temperature, while it was negatively correlated with humidity and cloud cover. In the post-peak period, a negative correlation was demonstrated between pollen concentration and minimum air temperature, rainfall, and humidity (Table 4).

The analysis of the Spearman's correlations shows that the season start date depended on air temperature (mean, minimum, and maximum) in February and March. The pollen season lasted longer when temperature in February was higher. The date of maximum concentration was shown to be dependent on average and minimum temperature in the entire pollen season as well as on average and maximum temperature in April. With higher seasonal temperature, the seasonal maximum occurred later (a positive correlation), while with higher temperature in April, the maximum occurred earlier (a negative correlation) (Table 4).

Based on the analysis of the patterns of daily birch pollen concentrations, one can conclude that pollen concentration increases with increasing temperature, whereas during rainfall events the concentration of pollen grains falls (Fig. 6). These relationships were confirmed statistically. One clear peak generally occurred during the birch pollen season in Lublin. The curves in the years 2006 and 2008 were double-peaked, which was probably attributable to rainfall events during the time when the birch trees shed pollen (Figs 6, 7).

Table 4.

Significant Spearman's correlations between the parameters of the birch pollen season and meteorological factors

\begin{tabular}{|c|c|c|}
\hline Season parameter & Meteorological data & Spearman's coefficient \\
\hline \multicolumn{3}{|c|}{ Pollen concentration in season (all seasons included) } \\
\hline & Rainfall in season & $-0,14$ \\
\hline & Humidity in season & $-0,22$ \\
\hline \multicolumn{3}{|c|}{ Pollen concentration in pre-peak period (all seasons included) } \\
\hline & Mean temperature & 0,67 \\
\hline & Minimum temperature & 0,52 \\
\hline & Maximum temperature & 0,70 \\
\hline & Humidity & $-0,37$ \\
\hline & Cloud cover & $-0,29$ \\
\hline \multicolumn{3}{|c|}{ Pollen concentration in post-peak period (all seasons included) } \\
\hline & Minimum temperature & $-0,18$ \\
\hline & Rainfall & $-0,18$ \\
\hline & Humidity & $-0,28$ \\
\hline \multicolumn{3}{|l|}{ Start of season } \\
\hline & Mean temperature in February & $-0,67$ \\
\hline & Mean temperature in March & $-0,67$ \\
\hline & Minimum temperature in February & $-0,75$ \\
\hline & Minimum temperature in March & $-0,69$ \\
\hline & Maximum temperature in February & $-0,67$ \\
\hline & Maximum temperature in March & $-0,69$ \\
\hline \multicolumn{3}{|l|}{ Duration of season } \\
\hline & Mean temperature in February & 0,65 \\
\hline & Minimum temperature in February & 0,73 \\
\hline & Maximum temperature in February & 0,65 \\
\hline \multicolumn{3}{|c|}{ Date of seasonal maximum } \\
\hline & Mean temperature in season & 0,66 \\
\hline & Minimum temperature in season & 0,74 \\
\hline & Mean temperature in April & $-0,78$ \\
\hline & Maximum temperature in April & $-0,69$ \\
\hline
\end{tabular}



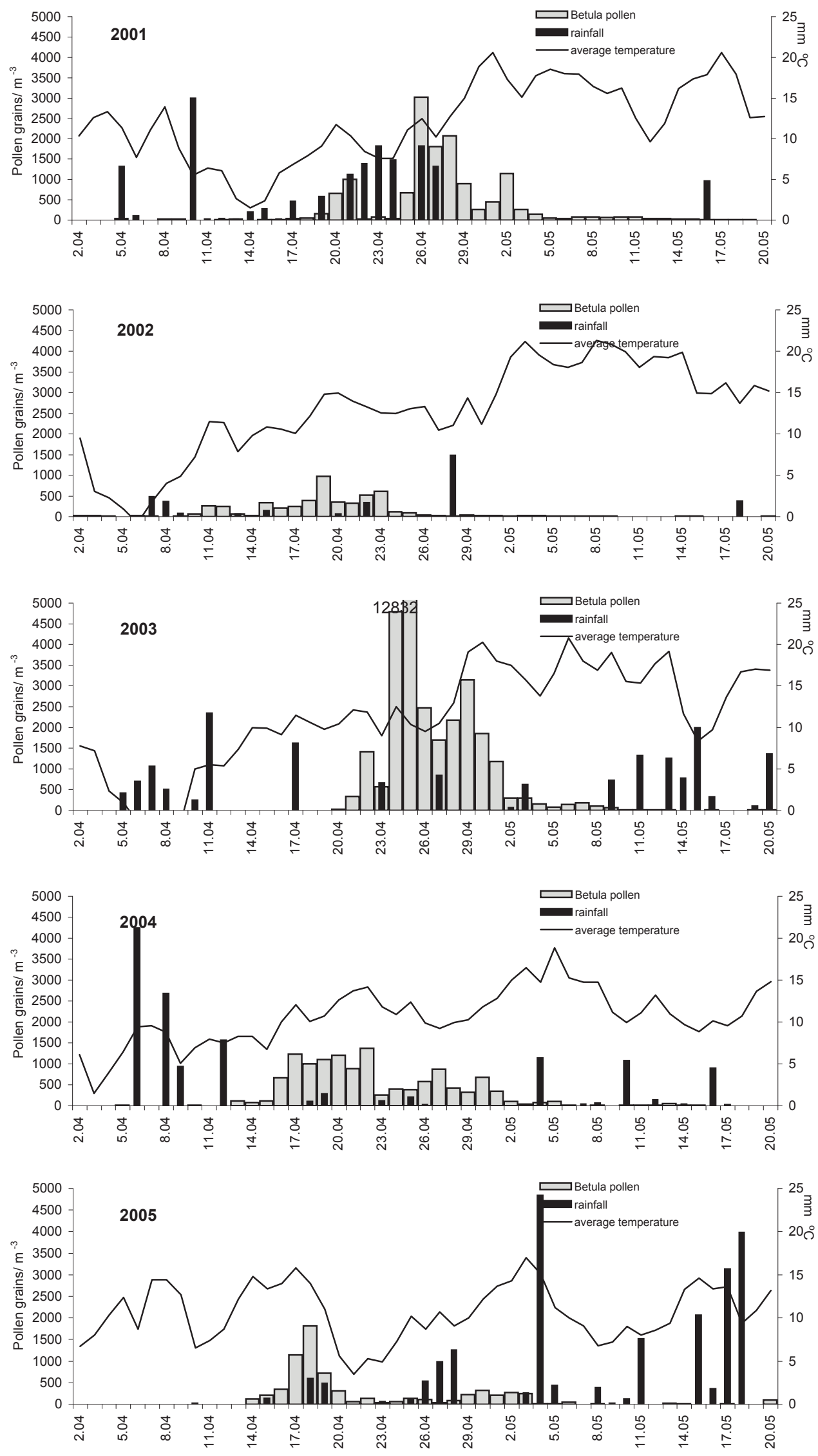

Fig. 6. Betula pollen grains concentration, in relation to the meteorological factors, 2001-2005. 

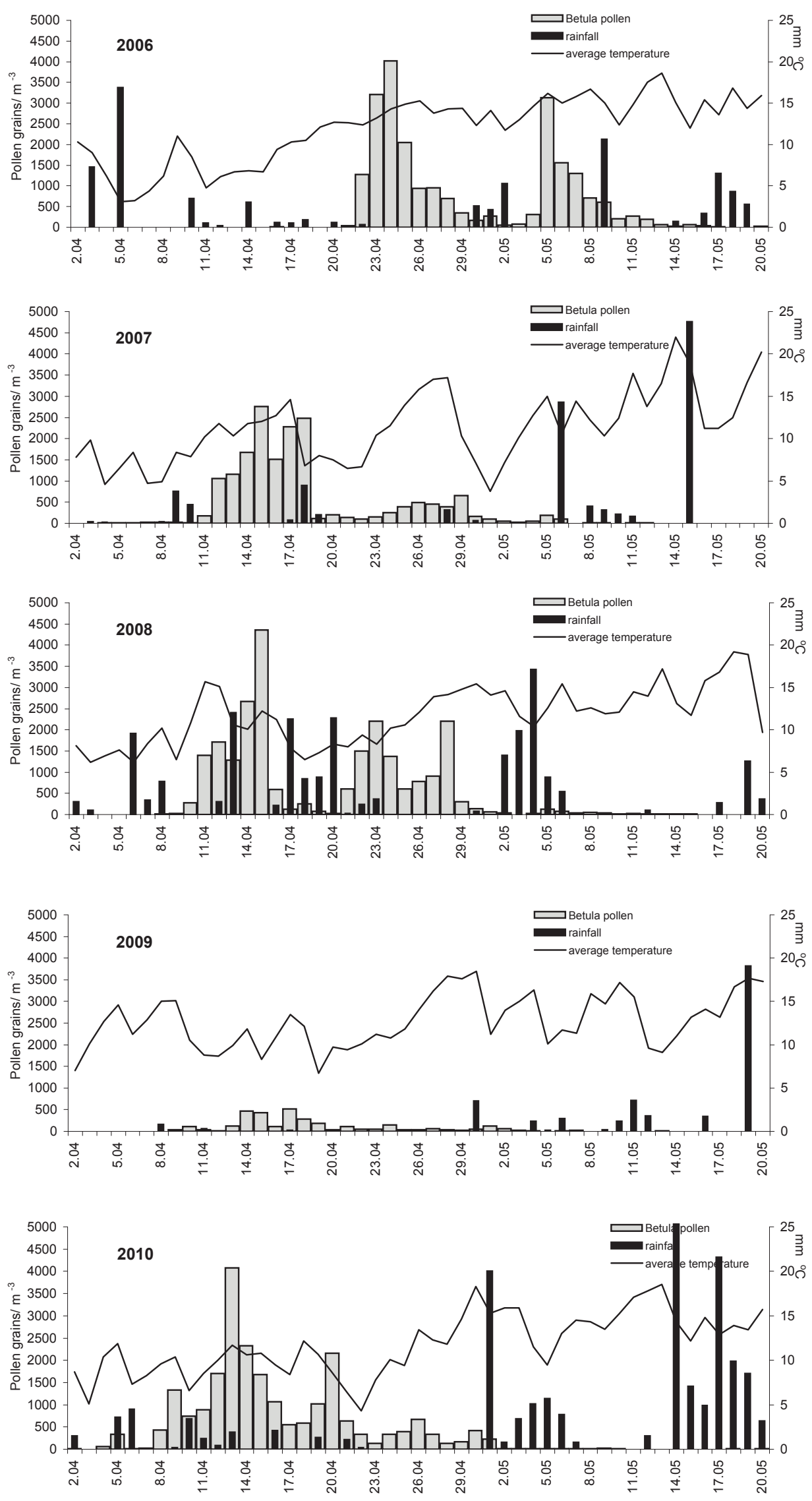

Fig. 7. Betula pollen grains concentration, in relation to the meteorological factors, 2006-2010. 


\section{DISSCUSION}

In comparison to the content of pollen of other plants in the aeroplankton of Lublin, the pollen of Betula ranks first among trees, while it is second after Urtica if the pollen of all plant taxa is taken into account (Weryszko-Chmielewska and Piot r o w s k a, 2004). Very high values for annual Betula pollen counts recorded in Lublin are comparable to annual birch pollen totals observed in Germany (Dalmenhorst) and the Netherlands (Helmond) (S p i e k s $\mathrm{m}$ a et al. 2003) where, likewise in Lublin, the trees belonging to this genus grew in close vicinity to the pollen trap. Over the period 2001-2010, the percentage of birch pollen grains in the pollen spectrum in Lublin was $6.5-37.9 \%$, averaging $22 \%$. These are values that are close to those obtained by S z c z e p a n e k (1994) in his 10-year study carried out in Kraków.

In order to reduce the effect of long-distance pollen transport and secondary redeposition, the pollen season is determined using various methods. Low pollen concentrations at the beginning and end of the season are usually eliminated. This prevents erroneous conclusions during statistical analysis (E mberlin et al. 1994; G a l a n et al. 1995). The duration and timing of pollen seasons are most frequently determined by using the percentage methods, according to which the pollen season includes $98 \%$ (E m b e r l i n, 1993), 95\% (Andersen, 1991), or 90\% (Nilss on and P e r s s o n , 1981) of pollen grains of a given taxon counted within the year. The practical importance of pollen monitoring is related primarily to pollen allergies. When deciding which method to apply during investigations, attention should be paid to ensure that we do not eliminate from a given season too large amounts of pollen grains that may cause allergies.

The threshold value, at which allergy symptoms occur in most persons allergic to Betula pollen, is $80 \mathrm{P} / \mathrm{m}^{3}$ per day (Vik et al. 1991; Rapiejko and Lipiec, 2005). In Lublin daily birch pollen concentration during the full season tends to significantly exceed this value. High pollen concentrations are usually observed already at the beginning of the birch pollen season. Within a short period of time, the birch trees release huge amounts of pollen into the atmosphere. Pollen grains eliminated in the determination of the season could be of some importance when evaluating the incidence of symptoms in allergic people.

The onset of the pollen season for spring flowering plants depends primarily on air temperature in the first months of the year (E m b e r lin et al. 2002). In Lublin a correlation was found between the start date of the birch pollen season and temperature in February and in March. P u c (2006) found a statistically significant correlation of seasonal birch pollen concentration with maximum air temperature and relative humidity. In Lublin we also found a significant influence of relative air humidity on pollen concentration, whereas temperature, in particular maximum temperature, was correlated in Lublin with pollen concentration during the pre-peak period.

Based on long-term studies of the annual total, Spieksma et al. (2003) found that the trend for birch pollen is increasing in Western Europe. In addition to increased birch pollen concentrations, earlier start dates of the pollen season have been observed for this taxon. According to Clot (2001), the birch pollen season begins 19 days earlier than 20 years ago. Various research centres (London, Brussels, Zurich, Vienna) predict earlier start dates of the birch pollen season, which is associated with high temperatures in the spring (E m b e r lin et al. 2002). According to the same authors, in Kevo (Finland) a trend towards cooler springs and later starts is noticeable. Therefore, pollen calendars and local predictive models are needed (E mberlin et al. 2002). This is particularly important for allergic people who may feel the effect of earlier and more intense birch pollen seasons.

In Lublin aerobiological research has been carried out since 1995; the gravimetric method was initially used for pollen monitoring, and in 2001 it was replaced by the volumetric method (WeryszkoChmielewska and Piotrowska, 1997; Piotrow s ka, 2006). This is too short a series of data to be able to draw any conclusions about increasing or decreasing trends, even more so that the data obtained using different methods cannot be compared. Nevertheless, the long-term results of meteorological observations, which show an increase in temperature in Lublin in the recent years, may suggest that an earlier onset of the birch pollen season can also be observed in this region.

This paper presents preliminary results of the study of the birch pollen seasons in Lublin and their correlations with meteorological factors. These data will be the subject of further analysis in order to fit the predictive models to the conditions prevailing in Lublin.

\section{CONCLUSIONS}

A comparison of three methods $(98 \%, 95 \%$, and 90\%) used to determine the start and end dates of birch pollen seasons shows that, from the point of view of the needs of allergology, the $98 \%$ method should be used in Lublin. The application of the $95 \%$ or $90 \%$ methods with respect to the taxa that, likewise birch, release very large amounts of pollen into the atmosphere entails the elimination from the season of days with high pollen concentration, during which symptoms may occur in most allergic persons. 
On the basis of correlation analysis, pollen concentration in the pollen season was demonstrated to be dependent primarily on rainfall and relative air humidity. Higher correlation coefficients were obtained when the pre- and post-peak periods were separated. In the pre-peak period, pollen concentration was positively correlated with air temperature, while it was negatively correlated with humidity and cloud cover. In the postpeak period, a negative correlation was found between birch pollen concentration and minimum air temperature, rainfall and humidity. The onset and duration of the birch pollen season as well as the date of the seasonal maximum mainly depended on air temperature.

Average air temperature in Lublin in the period 2001-2010 was higher than in the period 1951-2010 by $1.0^{\circ} \mathrm{C}$. The increasing trend in air temperature in the months January-April, which continued in the next years, can cause an earlier appearance of birch pollen in the air and an increase in its concentration. This is important information both for people suffering from pollen allergies and for allergists.

\section{REFERENCES}

Andersen T.B., 1991. A model to predict the beginning of the pollen season. Grana, 30: 269-275.

B a n a z zak J., 1993. Ekologia pszczół. Wyd. Nauk. PWN, Warszawa - Poznań (in Polish).

Chiesura A., 2004. The role of Urban Parks for the Sustainable City Landscape. Landscape Urban Plan. 68: 129-138.

Clot B ., 2001. Airborne birch pollen in Neuchâtel (Switzerland): onset, peak and daily patterns. Aerobiologia, 17: 25-29.

Emberlin J., Savage M., Woodman R., 1993. Annual variations in the concentrations of Betula pollen in the London area, 1961-1990. Grana, 32: 359-363.

Emberlin J., Jones S., Bailey J., Caulton E., Corden J., Dubbels S., Evans J., McDonagh N., Millington W., Mullins J., Russel R., Spencer T., 1994. Variation in the start of the grass pollen season at selected sites in the United Kingdom 1987-1992. Grana, 33: 94-99.

Emberlin J., Detandt M., Gehrig R., Jaeger S., Nolard N., Rantio-Lehtimäki A., 2002. Responses in the start of Betula (birch) pollen seasons to recent changes in spring temperatures across Europe. Int. J. Biometeorology, 46: 159-170.

Galán C., Emberlin J., Dominguez E., Bryant R.H., Villamandos F., 1995. A comparative analysis of daily variations in the Gramineae pollen counts at Córdoba, Spain and London, UK. Grana, 34: 189-198.

Ka s zew sk i B. M ., 2008. Klimat. [In:] S. Uziak, R. Turski (eds) Środowisko przyrodnicze Lubelszczyzny. LTN, Lublin: 75-111 (in Polish).
Kreme r B.T., 1996, Drzewa. Wyd. Świat Książki, Warszawa (in Polish).

Maurizio A., 1953. Weitere Untersuchungen an Pollenhöschen. Beihefte zur Schweizerizchen Bienen-Zeitung, 2 (20): 485-556 (in German).

Maurizio A., Grafl I., 1969. Das Trachtpflanzenbuch. Band 4. Ehrenwirth Verlag, München (in German).

Nilss on S., Persson S., 1981. Tree pollen spectra in the Stockholm region (Sweden), 1973-1980. Grana, 20: 179-182.

Nils s o n S ., 1990. Regional and global distribution of aeroallergens. Rev. Palaeobot. Palynol. 64: 29-34.

Piotrowska K., 2006. Kalendarz pyłkowy dla Lublina, 1995-2000. / Pollen calendar of Lublin, 1995-2000. Acta Agrobot., 59 (1): 529-538 (in Polish).

P u c M., 2006. Pyłek brzozy w powietrzu Szczecina w latach 2000-2004. / Birch pollen in the air of Szczecin In 20002004. Acta Agrobot. 59 (1): 325-333 (in Polish).

Rapiejko P., Lipiec A., 2005. Alergeny pyłku brzozy. / The birch pollen allergens. Alergorofil, 1 (1): 42-47 (in Polish).

Spieksma F.Th.M, Corden J.M., Detandt M., Millington W.M., Nikkels H., Nolard N., Schoenmakers C.H.H., Wachter R., de Weger L.A., Willems R., Emberlin J., 2003. Quantitative trends in annual totals of five common airborne pollen types (Betula, Quercus, Poaceae, Urtica and Artemisia), at five pollen -monitoring stations in western Europe. Aerobiologia, 19: 171-184.

Szczepanek K., 1994. Pollen calendar for Cracow (Southern Poland), 1982-1991. Aerobiologia, 10: 65-70.

Szweykowscy A. J., 1993. Słownik botaniczny. Wiedza Powszechna, Warszawa (in Polish).

Ulrich R.S., 1984. View from a Windows may influence recovery from sugery. Science, 224: 420-421.

Uryga J., 2002. Nasze drzewa. Wyd. Duszpasterstwa Rolników, Włocławek (in Polish).

Vik H., Florvaag E., Elsayed S., 1991. Allergenic significance of Betula (birch) pollen. In: G. D'Amato, F.Th.M. Spieksma, S. Bonini (eds), Allergenic pollen and pollinosis in Europe, Blackwell Sci. Publ., Oxford, 94-97.

Warakomska Z., 1997. Obraz pyłkowy wielokwiatowych miodów Lubelszczyzny. / Pollen spectrum of multiflorous honey of Lublin region. Mat. I Ogólnopol. Konf. Nauk. „Biologia kwitnienia, nektarowania i zapylania roślin”, Lublin: 170-177 (in Polish).

Weryszko-Chmielewska E., Piotrowska K., 1997. Analiza zawartości pyłku w aeroplanktonie Lublina i okolic w latach 1995 i 1996. / The analysis of pollen content in aeroplankton of Lublin region in 1995 and 1996 years. Mat. I Ogólnopol. Konf. Nauk. „Biologia kwitnienia, nektarowania i zapylania roślin”, Lublin 13-14.11.1997: 215-221 (in Polish).

Weryszko-Chmielewska E., Piotrowska K., 2004. Airborne pollen calendar of Lublin, Poland. Ann Agric Environ Med, 11: 91-97. 
Zając A., Zając M., 2001. (eds), Atłas rozmieszczenia roślin naczyniowych w Polsce. Wyd. Instytutu Botaniki UJ, Kraków (in Polish).

\section{Zmienność sezonów pyłkowych brzozy (Betula spp.) w Lublinie i korelacje z czynnikami meteorologicznymi w latach 2001-2010.}

\section{Badania wstępne}

Streszczenie

W Polsce brzoza należy do najważniejszych taksonów wytwarzających alergogenny pyłek, dlatego informacja o terminach rozpoczęcia, czasie trwania i intensywności sezonu pyłkowego jest bardzo ważna dla lekarzy alergologów i ich pacjentów oraz klimatologów. Badania dotyczące monitoringu pyłkowego brzozy prowadzono w Lublinie przy zastosowaniu metody wolumetrycznej w latach 2001-2010. Aparat Lanzoni VPPS 2000 umieszczony był w centrum miasta na wysokości $18 \mathrm{~m}$. Sezon pyłkowy oznaczono trzema metodami: $98 \%, 95 \%, 90 \%$. W pracy badano również zależności cech sezonu pyłkowego brzozy od czynników meteorologicznych. Z porównania wymienionych metod wynika, że w warunkach Lublina najbardziej odpowiednią metodą do wyznaczania sezonu pyłkowego brzozy jest metoda $98 \%$, ponieważ przy pozostałych dwóch metodach z sezonu eliminowane są zbyt duże ilości ziaren pyłku. Na podstawie analizy porównawczej danych meteorologicznych z okresu badań i wielolecia można stwierdzić, że w Lublinie w ostatnich latach notowany jest wyraźny wzrost temperatury powietrza. Stwierdzono istotną statystycznie ujemną korelację między stężeniem pyłku w sezonie a opadami deszczu i wilgotnością powietrza. Po wydzieleniu okresu prepeak i post-peak korelacje były większe i dotyczyły różnych czynników meteorologicznych. Początek sezonu pyłkowego był ujemnie skorelowany z temperaturą w lutym i marcu. Długość sezonu zależała od temperatury w lutym (korelacja dodatnia). Data maksimum sezonowego była skorelowana dodatnio z temperaturą $\mathrm{w}$ sezonie i ujemnie $\mathrm{z}$ temperaturą $\mathrm{w}$ kwietniu. 